\title{
PENGARUH MOTIVASI DAN GAYA KEPEMIMPINAN TERHADAP KEDISIPLINAN PEGAWAI
}

\author{
Mohd. Heikal \\ Fakultas Ekonomi dan Bisnis Universitas Malikussaleh
}

\begin{abstract}
ABSTRAK
Penelitian ini bertujuan untuk mengetahui pengaruh motivasi terhadap Disiplin Kerja pegawai pada Kantor Kesehatan Pelabuhan Kelas I Medan , untuk mengetahui pengaruh Gaya Kepemimpinan terhadap Disiplin Kerja pegawai pada Kantor Kesehatan Pelabuhan Kelas I Medan, untuk mengetahui pengaruh motivasi dan Gaya Kepemimpinan secara simultan terhadap Disiplin kerja pegawai pada Kantor Kesehatan Pelabuhan Kelas I Medan. Populasi dalam penelitian ini adalah seluruh pegawai tetap Kantor Kesehatan Pelabuhan Kelas I Medan yang berjumlah 104 orang. Sampel dalam penelitian ini berjumlah 83 orang. Teknik pengumpulan data yang digunakan dalam penelitian ini yaitu daftar pernyataan (Quesioner). Sedangkan teknik analisis data menggunakan, Uji Asumsi Klasik, regresi linier berganda, Uji t, Uji F dan Koefisien Determinasi. Hasil analisis manunjukkan bahwa terdapat pengaruh yang signifikan antara variabel Motivasi $\left(\mathrm{X}_{1}\right)$ terhadap Disiplin $(\mathrm{Y})$ ditunjukan oleh nilai probabilitas sig. $0,000 \leq \alpha 0,05$. Hal tersebut berarti bahwa hipotesis nol (H0) ditolak dan (Ha) diterima dapat disimpulkan bahwa Motivasi $\left(\mathrm{X}_{1}\right)$ secara parsial memberikan pengaruh yang signifikan terhadap Disiplin Kerja Pegawai (Y). Adanya pengaruh variabel Gaya Kepemimpinan $\left(\mathrm{X}_{2}\right)$ terhadap Disiplin kerja Pegawai $(\mathrm{Y})$ yang ditunjukkan pada nilai probabilitas sig. $0,000 \leq 0,05$. Hal tersebut berarti bahwa hipotesis nol (H0) ditolak dan (Ha) diterima dapat disimpulkan bahwa Gaya kepemimpinan $\left(\mathrm{X}_{2}\right)$ secara parsial mempunyai pengaruh yang signifikan terhadap Disiplin Kerja Pegawai (Y). Adanya pengaruh signifikan antara Motivasi $\left(\mathrm{X}_{1}\right)$ dan Gaya Kepemimpinan $\left(\mathrm{X}_{2}\right)$ terhadap Disiplin Kerja Pegawai (Y) yang ditunjukan oleh uji $\mathrm{F}$ dengan nilai sig $0,000<\alpha 0,05$ menunjukkan H0 ditolak dan Ha diterima, berarti Motivasi dan Gaya Kepemimpinan berpengaruh secara signifikan terhadap Disiplin Kerja Pegawai.
\end{abstract}

Kata kunci : Motivasi, Gaya Kepemimpinan dan Disiplin.

\section{PENDAHULUAN}

Kelancaran suatu perusahaan akan sangat membutuhkan ketaatan dari anggotanya sehingga peraturan dan ketentuan yang berlaku pada perusahaan tersebut. Dengan kata lain disiplin kerja pada pegawai sangat dibutuhkan, karena apa yang menjadi tujuan perusahaan akan sukar dicapai bila tidak ada disiplin kerja.

Menurut Sutrisno (2009, hal. 90) menyatakan bahwa arti penting dari disiplin kerja yaitu: Dengan dipunyainya disiplin kerja yang baik, berarti akan dicapai pula suatu keuntungan yang berguna, baik bagi perusahaan maupun bagi pegawai sendiri. 


\section{LANDASAN TEORI \\ Disiplin Kerja}

Kekurang disiplinan di dalam manajemen suatu organisasi juga dapat mengakibatkan kerugian bahkan jatuhnya organisasi itu sendiri. Dari sisi pegawai banyak yang melanggar disiplin.kedisiplinan yang dimiliki perusahaan akan menjadikan perusahan itu sendiri lebih maju.

Menurut siagaian(2009 hal.290) menyatakan pendisiplina pegawai adalah suatu bentuk pelatihan yang berusaha memperbaiki dan membentuk ilmu pengetahuan sikap dan perilaku pegawai tersebut secara sukarela berusaha bekerja secara kooperatif denagn para pegawai lainya serta meningktakan prestasiMenurut Sulistiyani dan Rosidah (2009, hal. 290) menyatakan bahwa "disiplin (discipline) adalah prosedur yang mengkoreksi atau menghukum bawahan karana melanggar peraturan atau prosedur. Menurut Siagian (2009, hal. 305) :

Adapun Manfaat Disiplin Kerja Keteraturan adalah ciri utama organisasi dan disiplin adalah salah satu metode untuk memelihara keteraturan tersebut. Menurut Sutrisno (2009, hal. 92) tujuan utama disiplin adalah untuk meningkatkan efisiensi semaksimal mungkin dengan cara mencegah pemborosan waktu dan energi. Selain itu, disiplin mencoba untuk mencegah kerusakan atau kehilangan harta benda, mesin, peralatan dan perlengakapan kerja yang disebabkan oleh ketidak hatian-hatian, senda gurau atau pencurian.

\section{Faktor-Faktor yang Mempengaruhi Disiplin Kerja}

Menurut Singodimedjo dalam Sutrisno (2009, hal. 94-98) faktor yang mempengaruhi disiplin kerja adalah sebagai berikut:

1) Besar kecilnya pemberian kompensasi

2) Ada tidaknya keteladanan pimpinan dalam perusahaan

3) Ada tidaknya aturan pasti yang dapat dijadikan pegangan

4) Keberanian pimpinan dalam mengambil tindakan.

\section{Pengertian Motivasi}

Motivasi dapat diartikan sebagai dorongan yang membuat orang bekerja atau melakukan tindakan tertentu, semangat orang bertindak kearah satu tujuan adalah motivasi. Semua prilaku yang dilakukan seseorang pada umumnya adalah akibat dari motivasi pribadi yang ada pada diri orang tersebut. Untuk memperjelas pengertian motivasi maka akan dikutip pendapat beberapa ahli tentang pengertian beberapa motivasi antara lain:

Motivasi berasal dari kata dasar motif yang berarti dorongan pada sifat manusia untuk berbuat dan bertindak. Menurut Hasibuan (2007, hal. 92) motivasi mempersoalkan bagaimana caranya mendorong gairah kerja bawahan, agar mereka mau bekerja keras dengan memberikan semua kemampuan dan keterampilannya untuk mewujudkan tujuan perusahaan.

Hasibuan (2007, hal. 95) motif adalah suatu perangasang keinginan dan daya penggerak kemauan bekerja seseorang setiap motif mempunyai tujuan tertentu yang ingin dicapai.

Rivai (2009, hal. 837) Motivasi adalah serangkaian sikap dan nilai-nilai yang mempengaruhi individu untuk mencapai hal yang spesifik sesuai dengan tujuan individu. Sikap dan nilai tersebut merupakan suatu yang visible yang memberikan kekuatan untuk mendorong individu bertingkah laku dalam mencapai tujuan. 
Dari pendapat di atas didefinisikan bahwa motivasi adalah merupakan pendorong atau penggerak seseorang untuk mau bertindak dan bekerja dengan giat sesuai dengan tugas dan kewajibannya. Kemudian pegawai yang termotivasi sangat mengerti tujuan dan tindakan mereka dan juga meyakini bahwa tujuan tersebut akan tercapai sesuai dengan apa yang sudah direncanakan.

Menurut Mengkunegara (2007, hal. 111) petunjuk penilaian untuk daftar pertanyaan mengenai motivasi berprestasi yaitu:

$\begin{array}{ll}\text { 1. } & \text { Kerja Keras } \\ \text { 2. } & \text { Orientasi Masa Depan } \\ \text { 3. } & \text { Tingkat Cita-cita yang Tinggi } \\ \text { 4. } & \text { Orientasi Tugas/Sasaran } \\ \text { 5. } & \text { Usaha untuk Maju } \\ \text { 6. } & \text { Ketekunan } \\ \text { 7. } & \text { Rekan kerja yang dipilih } \\ \text { 8. } & \text { Pemanfaatan waktu }\end{array}$

\section{Pengertian Kepemimpinan}

Dalam suatu organisasi, faktor kepemimpinan memegang peranan yang penting karena pemimpin itulah yang akan menggerakkan dan mengarahkan organisasi dalam mencapai tujuan dan sekaligus merupakan tugas yang tidak mudah. Tidak mudah, karena harus memahami setiap perilaku bawahan yang berbeda-beda. Bawahan dipengaruhi sedemikian rupa sehingga bisa memberikan pengabdian dan partisipasinya kepada organisasi secara efektif dan efisien. Dengan kata lain, dapat dikatakan bahwa sukses tidaknya usaha pencapaian tujuan organisasi, ditentukan oleh kualitas pimpinan.

Menurut Sutrisno (2009, hal. 231) menyatakan bahwa: "kepemimpinan adalah suatu proses kegiatan seseorang untuk menggerakan orang lain dengan memimpin, membimbing, mempengaruhi orang lain, untuk melakukan sesuatu agar dicapai hasil yang diharapkan.”

Berdasarkan beberapa pengertian di atas dapat disimpulkan bahwa kepemimpinan merupakan suatu proses mempengaruhi dan mengarahkan perilaku orang lain, baik individu maupun kelompok untuk mencapai tujuan tertentu. Dalam kepemimpinan terdapat unsur-unsur seperti pimpinan, kelompok yang dipimpin, sasaran, aktivitas, interaksi dan kekuatan.

G.R. Terry dalam Kartini Kartono (2008, hal. 61) mengemukakan tujuh teori kepemimpinan sebagai berikut:

1. Teori Psikologis (the psychologic theory)

2. Teori Sosiologis (the sosiologic theory)

3. Teori Supportif (the supportive theory)

4. Teori Laissez faire (the laissez-faire theory);

5. Teori Perilaku pribadi (the personal - behaviour theory)

6. Teori Sifat (the trait theory)

7. Teori Situasi (the situational theory). 


\section{Kerangka Konseptual}

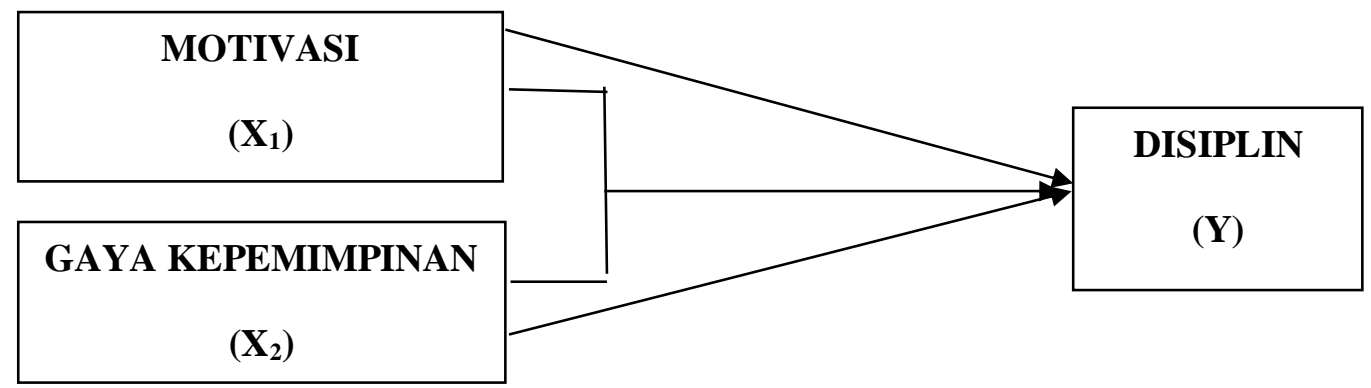

Gambar 3: Paradigma Penelitian

\section{Hipotesis}

Berdasarkan batasan dan rumusan permasalahan yang telah dikemukakan sebelumnya, maka hipotesis penelitian ini adalah:

1. Ada pengaruh motivasi terhadap disiplin kerja pegawai pada Kantor Kesehatan Pelabuhan Kelas I Medan.

2. Ada pengaruh gaya kepemimpinan terhadap disiplin kerja pegawai pada Kantor Kesehatan Pelabuhan Kelas I Medan.

3. Ada pengaruh motivasi dan gaya kepemimpinan terhadap disiplin kerja pegawai pada kantor Kesehatan Pelabuhan Kelas I Medan.

\section{METODOLOGI PENELITIAN}

\section{Pendekatan Penelitian}

Penelitian menggunakan pendekatan asosiatif untuk mengetahuai hubungan setiap variabel. Penulis mengumpulkan data dengan menyebarkan angket pada 83 pegawai. Data yang dikumpulkan disajikan dalam bentuk data kuantitatif.

\section{Teknik Analisis Data}

Teknik analisis yang digunakan dalam penelitian ini adalah analisis data kuantitatif, yakni menguji dan menganalisis data dengan perhitungan angka-angka dan kemudian menarik kesimpulan dari pengujian tersebut, dengan rumus-rumus di bawah ini:

\section{Pengujian Asumsi Klasik} antara lain:

Penggunaan Model Regresi Linier Berganda harus memenuhi asumsi klasik,

\section{Uji Normalitas}

Uji normalitas bertujuan untuk menguji apakah dalam model regresi, variabel pengganggu atau residual memiliki distribusi normal. Menurut Ghozali (2005) ada dua 
cara mendeteksi apakah residual berdistribusi normal atau tidak yaitu dengan analisis grafik dan uji statistik. Analisis grafik dengan melihat histogram dan normal plot sedangkan analisis statistik dilakukan dengan menggunakan uji statistik non parametrik Kolmogorov-Smirnov.

\section{Uji Multikolinieritas}

Uji multikolinieritas bertujuan untuk menguji apakah model regresi ditemukan adanya korelasi antar variabel bebas (independent). Model regresi yang baik seharusnya tidak terjadi korelasi di antara variabel independent. Jika variabel independen saling berkorelasi, maka variabel-variabel ini tidak ortogonal. Variabel ortogonal adalah variabel independen sama dengan nol. Menurut Ghozali (2005) multikolinieritas dapat dilihat dari (1) nilai tolerance dan lawannya (2) variance inflation factor (VIF). Kedua ukuran ini menunjukkan setiap variabel independen manakah yang dijelaskan oleh variabel independen lainnya.

\section{Uji Heteroskedastisitas}

Uji Heteroskedastisitas bertujuan untuk menguji apakah dalam model regresi terjadi ketidaksamaan variance dari residual satu pengamatan ke pengamatan yang lain. Jika variance dari residual satu pengamatan ke pengamatan lain tetap, maka disebut heteroskedastisitas.

\section{Regresi Berganda}

Model analisis data yang digunakan dalam penelitian untuk menganalisis adalah Regresi Linear Berganda (Multiple Regression) dengan model sebagai berikut:

$$
\begin{aligned}
& \mathrm{Y}=\mathrm{B}_{0}+\mathrm{B}_{1} \mathrm{X}_{1}+\mathrm{B}_{2} \mathrm{X}_{2}+\epsilon \\
& \text { Dimana: } \\
& \mathrm{Y}=\text { Disiplin kerja } \\
& \mathrm{X}_{1}=\text { Motivasi } \\
& \mathrm{X}_{2}=\text { Gaya kepemimpinan } \\
& \mathrm{B}_{0}=\text { Koefisien regresi } \\
& \mathrm{B}_{1}=\text { Koefisien Variabel } \mathrm{X}_{1} \\
& \mathrm{~B}_{2}=\text { Koefisien Variabel } \mathrm{X}_{2} \\
& \epsilon=\text { error of term }
\end{aligned}
$$

\section{Uji F}

Uji $F$ atau juga uji signifikan secara bersama-sama dimaksudkan untuk melihat kemampuan menyeluruh dari variabel bebas yaitu Motivasi $\left(X_{1}\right)$ dan Gaya Kepemimpinan $\left(X_{2}\right)$ untuk dapat menjelaskan tingkah laku atau keragaman variabel tidak bebas Disiplin Kerja (Y). Uji F juga dimaksudkan untuk mengetahui apakah semua variabel memiliki koefisien regresi sama dengan nol.

Bentuk Pengujian : 
H0: Tidak ada pengaruh antara Motivasi dan Disiplin terhadap Disiplin kerjaa Pegawai.

Ha : Ada pengaruh Motivasi dan Disiplin terhadap Disiplin kerja Pegawai.

Kreteria penerimaan/ penolakan hipotesis adalah sebgai berikut :

- Tolak H0 jika nilai probabilitas yang dihitung $\leq$ probabilitas yang ditetapkan sebesar 0,05 ( sig. $\leq 0,05$ )

- Terima H0 jika nilai probabilitas yang dihitung $\geq$ probabilitas yang ditetapkan sebesar 0,05 ( sig. $\geq 0,05$ )

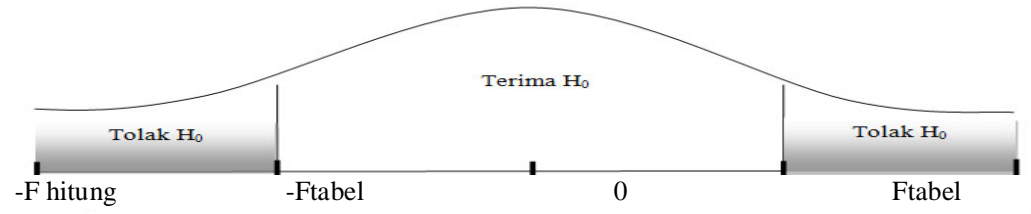

\section{Gambar IV-4 PENGUJIAN HIPOTESIS}

\section{Asumsi Klasik}

\section{Normalitas}

Pengujian normalitas data dilakukanuntuk melihat apakah model regresi, variabel dependen dan independennya memiliki distribusi normal atau baik. Berikut ini dibawah ini berdasarkan hasil uji normalitas kolmogrov smirnov dengan tujuan untuk menguji keseluruhan data yang berskala minimal ordinal maka digunakan uji kolmogrov smirnov

Tabel -8. Uji Normalitas Kolmogorov-Sminov Test One-Sample Kolmogorov-Smirnov Test

\begin{tabular}{|ll|r|r|r|}
\hline & & Motivasi & $\begin{array}{c}\text { Gaya } \\
\text { Kepemimpin } \\
\text { an }\end{array}$ & $\begin{array}{c}\text { Disiplin } \\
\text { Kerja }\end{array}$ \\
\hline $\mathrm{N}$ & 83 & 83 & 83 \\
Normal Parameters ${ }^{\mathrm{a}}$ & Mean & 58.8916 & 50.6265 & 42.1084 \\
& Std. Deviation & 4.64078 & 4.68446 & 4.02132 \\
Most Extreme & Absolute & .110 & .126 & .116 \\
Differences & Positive & .075 & .079 & .068 \\
Kolmogorov-Smirnov Z & -.110 & -.126 & -.116 \\
Asymp. Sig. (2-tailed) & 1.002 & 1.145 & 1.055 \\
\hline
\end{tabular}

a. Test distribution is Normal.

Sumber : Data diolah, 2015

Kriteria untuk menentukan normal atau tidaknya data, maka dilihat pada nilai probabilitasnya. Data adalah normal, jika nilai kolmogorov smirnov adalah tidak signifikan (Asymp. Sig (2-tailed) $>\alpha 0,05$. Berdasarkan data tabel uji normalitas di atas dengan nilai $X_{1}=0,268, X_{2}=0,145$ dan $Y=0,216$ dengan demikian dapat dipahami 
bahwa $H_{0}$ diterima. Untuk lebih jelasnya dapat dilihat pada gambar normal P-P plot of regression standardized residual pada gambar dibawah ini :

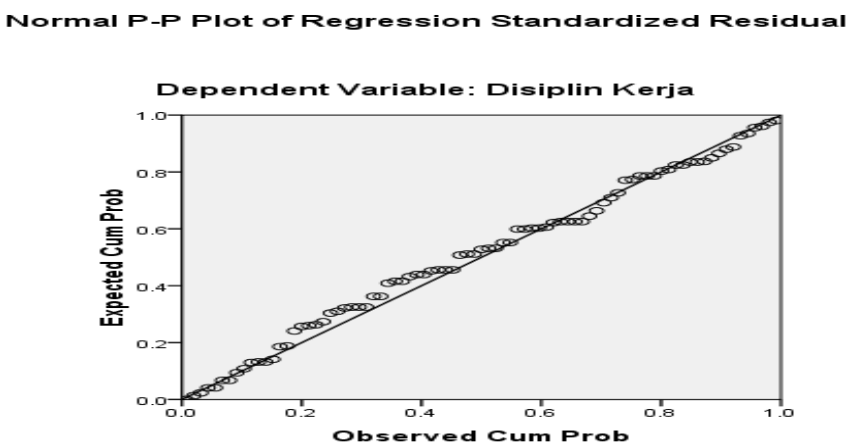

Gambar 2. Uji Normalitas

Berdasarkan gambar di atas mengidentifikasikan bahwa model regresi telah memenuhi asumsi yang telah dikemukakan sebelumnya, sehingga data dalam model regresi penelitian ini normal.

\section{Uji Multikolinieritas}

Uji multikolinearitas digunakan untuk menguji apakah pada model regresi ditemukan adanya korelasi yang kuat antar variabel independen. Dalam peneltian ini gejala multikolinearitas dilihat dari nilai faktor infaksi varian (Variance Inflasi Faktor) VIF) yang tidak melebihi 4 atau 5. Hasil uji multikolinearitas dapat dilihat pada tabel berikut ini :

\section{Tabel 9. Multikolinearitas}

Coefficients $^{\mathrm{a}}$

\begin{tabular}{|l|r|r|r|r|r|}
\hline \multirow{2}{*}{ Model } & \multicolumn{3}{|c|}{ Correlations } & \multicolumn{1}{c|}{ Collinearity Statistics } \\
\cline { 2 - 6 } & Zero-order & Partial & \multicolumn{1}{c|}{ Part } & Tolerance & \multicolumn{1}{c|}{ VIF } \\
\hline $1 \quad$ (Constant) & & & & & \\
Motivasi & .972 & .183 & .028 & .043 & 23.104 \\
$\quad \begin{array}{l}\text { Gaya } \\
\text { Kepemiminan }\end{array}$ & .988 & .763 & .178 & .043 & 23.104 \\
\hline
\end{tabular}

a. Dependent Variable: Disiplin Kerja

Berdasarkan data uji multikolinearitas diatas kedua variabel independen yakni Motivasi dan Gaya Kepemimpinan memiliki nilai VIF diluar batas toleransi yang telah ditentukan (melebihi 5), yaitu hanya 23.104 sehingga terjadi multikolinearitas dalam variabel independen penelitian ini.

\section{Uji Heterokedastisitas}

Heterokedastisitas digunakan untuk mneguji apakah dalam model regresi, terjadi ketidaksamaan varians dari residual dari suatu pengamatan yang lain. Jika varians residual dari satu pengamatan ke pengamatan lain tetap, maka disebut homokedastisitas, 
dan jika varians berbeda disebut heterokedastisitas. Model yang baik adalah tidak terjadi heterokedastisitas.

Dasar pengambilan keputusannya adalah jika pola tertentu, seperti titik-titik (poin-poin) yang ada membentuk suatu pola tertentu yang teratur, maka terjadi heterokedastisitas. Jika tidak ada pola yang jelas, serta titik-titik (point-point) menyebar dibawah dan di atas angka 0 pada sumbu Y, maka tidak terjadi heterokedastisitas.

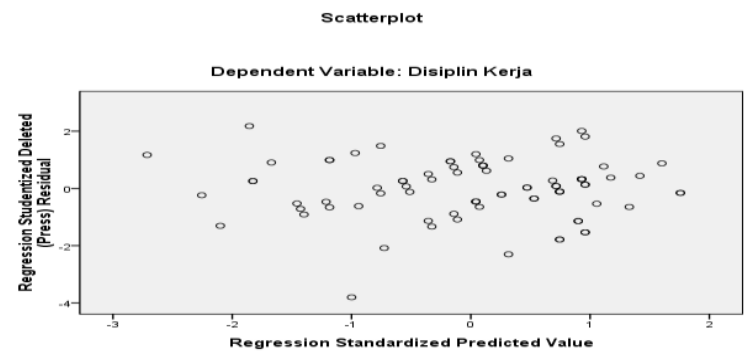

\section{Regresi Linier Berganda}

Dalam menganalisis data digunakan analisis regresi berganda. Analisis regresi berganda bertujuan untuk mengetahui pengaruh dari nilai motivasi dan gaya kepemimpinan serta untuk mengetahui hubungan antara variabel motivasi dan gaya kepemiminan secara bersama-sama terhadap variabel kinerja pegawai pada Kantor Kesehatan Pelabuhan Kelas I Medan.

Dengan rumus $\mathrm{Y}=\beta+\beta 1 X_{1}+\beta 2 X_{2}+\mathrm{e}$

Dimana :

$\mathrm{Y}=$ Disiplin Kerja

$\mathrm{a}=$ Konstanta

$\mathrm{b}=$ Besaran koefisienregresi dari masing-masing variabel

$X_{1}=$ Motivasi

$X_{2}=$ Gaya Kepemimpinan

Tabel 10. Regresi Linier

\begin{tabular}{|c|c|c|c|c|c|c|}
\hline \multicolumn{7}{|c|}{ Coefficients $^{\mathrm{a}}$} \\
\hline \multirow{2}{*}{\multicolumn{2}{|c|}{ Model }} & \multicolumn{2}{|c|}{$\begin{array}{c}\text { Unstandardized } \\
\text { Coefficients }\end{array}$} & \multirow{2}{*}{\begin{tabular}{|c|}
$\begin{array}{c}\text { Standardize } \\
\mathrm{d} \\
\text { Coefficients }\end{array}$ \\
Beta \\
\end{tabular}} & \multirow[b]{2}{*}{$\mathrm{t}$} & \multirow[b]{2}{*}{ Sig. } \\
\hline & & B & $\begin{array}{l}\text { Std. } \\
\text { Error }\end{array}$ & & & \\
\hline $\boldsymbol{H}$ & (Constant) & -1.985 & 1.011 & & -1.964 & .053 \\
\hline & Motivasi & .117 & .070 & .004 & 1.662 & .000 \\
\hline & $\begin{array}{l}\text { Gaya } \\
\text { Kepemiminan }\end{array}$ & .735 & .070 & .856 & $\begin{array}{r}10.55 \\
0\end{array}$ & .000 \\
\hline
\end{tabular}

a. Dependent Variable: Disiplin

Kerja 
Dari hasil pengujian yang ada pada tabel di atas. Dengan penggunaan program SPSS for windows versi 16.00 diperoleh koefisien-koefisienpersamaan regresi linier berganda sebagai berikut :

$\mathrm{a}=-1,985$

$\mathrm{X}_{1}=0,117$

$\mathrm{X}_{2}=0,735$

Persamaan regresinya dari nilai-nilai diatas adalah : $Y=-1,985+0,117 X_{1}+0,735 X_{2}$

Tabel 11. Regresi Linier

Coefficients $^{\mathrm{a}}$

\begin{tabular}{|c|c|c|c|c|c|c|}
\hline \multirow{2}{*}{\multicolumn{2}{|c|}{ Model }} & \multicolumn{2}{|c|}{$\begin{array}{l}\text { Unstandardized } \\
\text { Coefficients }\end{array}$} & \multirow{2}{*}{\begin{tabular}{c|}
$\begin{array}{c}\text { Standardize } \\
\mathrm{d} \\
\text { Coefficients }\end{array}$ \\
Beta
\end{tabular}} & \multirow[b]{2}{*}{$\mathrm{t}$} & \multirow[b]{2}{*}{ Sig. } \\
\hline & & B & $\begin{array}{l}\text { Std. } \\
\text { Error }\end{array}$ & & & \\
\hline \multirow[t]{3}{*}{1} & (Constant) & -1.985 & 1.011 & & -1.964 & .053 \\
\hline & Motivasi & .117 & .070 & .004 & 1.662 & .000 \\
\hline & $\begin{array}{l}\text { Gaya } \\
\text { Kepemiminan }\end{array}$ & .735 & .070 & .856 & $\begin{array}{r}10.55 \\
0\end{array}$ & .000 \\
\hline
\end{tabular}

a. Dependent Variable: Disiplin

Kerja

Dari hasil pengujian yang ada pada tabel IV. Dengan penggunaan program SPSS for windows versi 16.00 diperoleh koefisien-koefisienpersamaan regresi linier berganda sebagai berikut :

$\mathrm{a}=-1,985$

$\mathrm{X}_{1}=0,117$

$\mathrm{X}_{2}=0,735$

Persamaan regresinya dari nilai-nilai diatas adalah :

$\mathrm{Y}=-1,985+0,117 X_{1}+0,735 X_{2}$

\section{Uji t}

Uji t pada dasarnya bertujuan untuk menunjukkan seberapa jauh pengaruh satu variabel independen secara individual dalam menerangkan variabel dependen. Dengan bantuan komputer program Sta tistical Package For Social Science (SPSS 16.0).

Kriteria penerimaan/ penolakan hipotesis adalah sebgai berikut :

1) Bila Sig $>0,05$ maka $\mathrm{HO}=$ diterima, sehingga tidak ada pengaruh signifikan antara variabel bebas dan terikat.

2) Bila Sig $<0,05$ maka $\mathrm{HO}=$ ditolak, sehingga ada pengaruh signifikan antara variabel bebas dan terikat. 
Tabel 12. uji t

\begin{tabular}{|c|c|c|c|c|c|c|}
\hline \multicolumn{7}{|c|}{ Coefficients } \\
\hline \multirow{2}{*}{\multicolumn{2}{|c|}{ Model }} & \multicolumn{2}{|c|}{$\begin{array}{c}\text { Unstandardized } \\
\text { Coefficients }\end{array}$} & \multirow{2}{*}{\begin{tabular}{|c}
$\begin{array}{c}\text { Standardiz } \\
\text { ed } \\
\text { Coefficient } \\
\text { s }\end{array}$ \\
Beta
\end{tabular}} & \multirow[b]{2}{*}{$\mathrm{t}$} & \multirow[b]{2}{*}{ Sig. } \\
\hline & & B & $\begin{array}{l}\text { Std. } \\
\text { Error }\end{array}$ & & & \\
\hline \multirow[t]{3}{*}{1} & (Constant) & -1.985 & 1.011 & & -1.964 & .053 \\
\hline & Motivasi & .117 & .070 & .135 & 1.662 & .000 \\
\hline & $\begin{array}{l}\text { Gaya } \\
\text { Kepemiminan }\end{array}$ & .735 & .070 & .856 & 10.550 & .000 \\
\hline
\end{tabular}

a. Dependent Variable: Disiplin

Kerja

\section{Pengaruh Motivasi terhadap Disiplin Kerja}

$$
\begin{aligned}
& t_{\text {hitung }}=1,662 \\
& t_{\text {tabel }}=1,990
\end{aligned}
$$

Terlihat pada hasil Uji Parsial tabel diatas diperoleh $t_{\text {hitung }}$ untuk variabel Motivasi $\left(\mathrm{X}_{1}\right)$ sebesar 1,662. Dengan derajat kebebasan $(\mathrm{df})=\mathrm{n}-2=83-2=81$ dengan demikian kriteria pengambilan keputusannya adalah : karena besarnya $t_{\text {hitung }} 1,662<$ $\mathrm{t}_{\text {tabel }} 1,990$ dan diperoleh nilai sig pada motivasi $\left(\mathrm{X}_{1}\right) 0,00<0,05$ dikarenakan nilainya lebih dari $(0,05)$ maka berdasrkan ketentuan uji secara parsial dapat disimpulkan $\mathrm{H} 0$ diterima dan Ha ditolak yang berarti secara parsial Motivasi $\left(X_{1}\right)$ mempunyai pengaruh yang signifikan terhadap Displin kerja Pegawai (Y).

\section{Pengaruh Gaya Kepemimpinan terhadap Disiplin Kerja}

$$
\begin{aligned}
& { }^{\mathrm{t}} \text { hitung }=10,550 \\
& \mathrm{t}_{\text {tabel }}=1,990
\end{aligned}
$$

Diperoleh ${ }^{\mathrm{t}}$ hitung untuk variabel Disiplin $\left(X_{2}\right)$ sebesar 0,877 . Dengan derajat kebebasan $(\mathrm{df})=\mathrm{n}-2=83-2=81$ dengan demikian kriteria pengambilan keputusannya adalah : karena besarnya : karena besarnya $t_{\text {hitung }} 10,550<, t_{\text {tabel }}$ dan diperoleh nilai sig pada gaya kepemimpinan $\left(x_{2}\right) 0,00<0,05$ dikarenakan nilainya lebih kecil dari $(0,05)$ maka berdasrkan ketentuan uji secara parsial dapat disimpulkan H0 ditolak dan Ha diterima yang berarti secara parsial Gaya Kepemimpinan $\left(X_{2}\right)$ mempunyai pengaruh yang signifikan terhadap Disiplin Kerja (Y).

\section{Uji F}

Uji $\mathrm{F}$ atau juga uji signifikan secara bersama-sama dimaksudkan untuk melihat kemampuan menyeluruh dari variabel bebas yaitu Motivasi $\left(X_{1}\right)$ dan Gaya Kepemimpinan untuk dapat menjelaskan tingkah laku atau keragaman variabel tidak bebas Disiplin Kerja (Y). Uji F juga dimaksudkan untuk mengetahui apakah semua variabel memiliki koefisien regresi sama dengan nol. 


\section{Bentuk Pengujian :}

H0 : Tidak ada pengaruh antara Motivasi dan Disiplin terhadap Disiplin Pegawai.

Ha : Ada pengaruh Motivasi dan dan Gaya kepemimpinan terhadap disiplin kerja Pegawai.

Kreteria penerimaan/ penolakan hipotesis adalah sebgai berikut :

- Tolak H0 jika nilai probabilitas yang dihitung $\leq$ probabilitas yang ditetapkan sebesar 0,05 ( sig. $\leq 0,05)$

- Terima H0 jika nilai probabilitas yang dihitung $\geq$ probabilitas yang ditetapkan sebesar 0,05 ( sig. $\geq 0,05$ )

\section{Tabel IV- 12}

Uji F

ANOVA $^{b}$

\begin{tabular}{|c|c|c|c|c|c|c|}
\hline \multicolumn{2}{|c|}{ Model } & Sum of Squares & Df & Mean Square & $\mathrm{F}$ & Sig. \\
\hline 1 & Regression & 1295.782 & 2 & 647.891 & $1.714 \mathrm{E} 3$ & $.000^{\mathrm{a}}$ \\
\hline & Residual & 30.242 & 80 & .378 & & \\
\hline & Total & 1326.024 & 82 & & & \\
\hline
\end{tabular}

a. Predictors: (Constant), Gaya Kepemiminan, Motivasi

b. Dependent Variable: Disiplin Kerja

\section{Koefisien Determinasi}

Koefisien determinasi merupakan besaran yang menunjukkan besarnya variasi variabel dependen yang dapat dijelaskan oleh variabel independennya. Dengan kata lain, koefisien determinasi ini digunakan untuk mengukur seberapa jauh variabel bebas dalam menerangkan variabel terikatnya. Nilai koefisien determinasi ditentukan dengan nilai Adjusted $R$ Square sebagaimana dapat dilihat pada tabel dibawah ini :

Tabel 13. Koefisien Determinasi

Model Summary ${ }^{b}$

\begin{tabular}{|l|r|r|r|r|}
\hline Model & R & R Square & \multicolumn{1}{c|}{$\begin{array}{c}\text { Adjusted R } \\
\text { Square }\end{array}$} & $\begin{array}{l}\text { Std. Error of } \\
\text { the Estimate }\end{array}$ \\
\hline 1 & $\begin{array}{r}.989 \\
\mathrm{a}\end{array}$ & .977 & .977 & .61484 \\
\hline
\end{tabular}

a. Predictors: (Constant), Gaya Kepemiminan,

Motivasi

b. Dependent Variable: Disiplin Kerja

Berdasarkan hasil perhitungan regresi pada tabel di atas dapat diketahui bahwa koefisien determinasi yang diperoleh sebesar 0,997, hal ini memiliki arti bahwa 99,7\% variabel disiplin kerja dapat dijelaskan oleh variabel motivasi dan gaya kepemimpinan, sedangkan sisanya sebesar $0,3 \%$ diterangkan oleh variabel lain yang tidak diteiti.

Semakin tinggi nilai Adjusted $R$ Square maka akan semakin banyak bagi model regresi karena kemampuan variabel bebas untuk menjalankan variabel terikatnya juga semakin besar. 


\section{PEMBAHASAN}

Analisa hasil temuan penelitian ini adalah analisis mengenai hasil temuan penelitian ini terhadap kesesuain teori, pendapat, maupun penelitian terdahulu yang telah dikemukakan sebelumnya serta pola prilaku yang harus dilakukan untuk mengatasi hal tersebut. Berikut ini ada 3 (tiga) bagian utama yang akan dibahas dalam analisis hasil temuan penelitian ini, yaitu sebagai berikut:

\section{Pengaruh Motivasi ( $\left.\mathbf{x}_{1}\right)$ terhadap Disiplin Kerja (Y)}

Menurut Rivai (2009, hal 837) menyatakan "Motivasi adalah serangkaian sikap dan nilai-nilai yang mempengaruhi individu untuk mencapai hal yang spesifiksesuai dengan tujuan individu. Sikap dan nilai tersebut merupakan suatu yang visible yang memberikan kekuatan untuk mendorong individu bertimgkah laku dalam mencapai tujuan".

Dengan demikian diketahui bahwa motivasi merupakan pendorong atau penggerak seseorang untuk mau bertindak dan bekerja dengan giat sesuai dengan tugas dan kewajibannya. Kemudian pegawai yang termotivasi sangat mengerti tujuan dan tindakan mereka dan juga meyakini bahwa tujuan tersebut akan sesuai dengan apa yang sudah direncanakan.

Berdasarkan hasil pengujian secara parsial pengaruh antara Motivasi $\left(\mathrm{X}_{1}\right)$ terhadap Disiplin kerja Pegawai (Y) diperoleh nilai probabilitas sig. $0,00 \leq 0,05$. Hal tersebut berarti bahwa hipotesis nol (H0) diterima dan Ha ditolak. Dapat disimpulkan bahwa Motivasi $\left(\mathrm{X}_{1}\right)$ secara parsial tidak memberikan pengaruh yang signifikan terhadap Disiplin Kerja (Y) pada Kantor Kesehatan Pelabuhan Kelas I Medan.

\section{Pengaruh Gaya Kepemimpina ( $\left.\mathbf{x}_{2}\right)$ terhadap Disiplin Kerja (Y)}

Menurut Sutrisno (2009, hal.231) menyatakan:Kepemimpinan adalah suatu proses kegiatan seseorang untuk menggerakan orang lain dengan memimpin membimbing,mempengaruhi orang lain, untuk melakukan sesuatu agar dicapai hasil yang diharapkan.

Berdasarkan hasil penelitian diatas, ada pengaruh yang signifika pada variabel kepemimpinan $\left(\mathrm{X}_{2}\right)$ terhadap disiplin kerja $(\mathrm{Y})$ yang ditunjukkan pada probabilitas sig. $0,000 \leq 0,05$. Hal tersebut berarti bahwa hipotesis nol (H0) ditolak dan Ha diterima. Dapat disimpulkan bahwa Gaya Kepemimpinan $\left(\mathrm{X}_{2}\right)$ secara parsial memberikan pengaruh yang signifikan terhadap Disiplin Kerja (Y) pada Kantor Kesehatan Pelabuhan Kelas I Medan.

Hasil penelitian yang diperoleh sejalan dengan hasil penelitian terdahulu yang dilakukan oleh Trenadi Rama yang berjudul "Pengaruh Gaya Kepemimpinan Terhadap Disiplin Kerja Karyawan Di PT. Simi Solution". Berdasarkan penelitian ini dapat disimpulkan bahwa secara parsial (individu) terdapat pengaruh yang positif dan signifikan antara Gaya Kepemimpinan $\left(\mathrm{X}_{2}\right)$ terhadap Disiplin Kerja $(\mathrm{Y})$.

\section{Pengaruh Motivasi $\left(\mathrm{x}_{1}\right)$ dan Gaya kepemimpinan $\left(\mathrm{x}_{2}\right)$ secara simultan terhadap Disiplin kerja Pegawai (Y)}

Dari hasil penenlitian di atas, menunjukan tidak adanya pengaruh yang signifikan antara Motivasi $\left(\mathrm{X}_{1}\right)$ dan Gaya Kepemimpinan $\left(\mathrm{X}_{2}\right)$ terhadap Disiplin Kerja (Y) yang ditunjukan oleh uji $\mathrm{F}$ dengan nilai sig $0,000>\alpha 0,05$ menunjukkan H0 ditolak dan Ha diterima, berarti Motivasi dan Gaya Kepemimpinan tidak berpengaruh terhadap Disiplin Kerja. 


\section{Prosiding Seminar Nasional Ekonomi IV 2016 \\ " Membangun Ketahanan Ekonomi Nasional "}

Uhokseumawe, 15 November 2016

Hasil penenlitian yang diperoleh sesuai dengan penenlitian sebelumnya yang dilakukan oleh Aries Susanti, Sigit Baskoro (2011) yang berjudul "Pengaruh Motivasi dan Gaya Kepemimpinan terhadap Disiplin Kerja Karyawan Pegawai Pada Kantor Badan Narkotika Nasional (BNN) Kota Samarinda". Berdasarkan penelitian ini dapat disimpulkan bahwa Motivasi dan Gaya Kepemimpinan secara simultan berpengaruh terhadap Disiplin Kerja antara Motivasi $\left(\mathrm{X}_{1}\right)$ dan Gaya Kepemimpinan $\left(\mathrm{X}_{2}\right)$ Terhadap Disiplin Kerja (Y).

\section{PENUTUP}

\section{Kesimpulan}

Berdasarkan penelitian yang penulis lakukan, maka kesimpulan dari penelitian ini adalah sebagai berikut :

1. Dari hasil pengujian yang telah dilakukan di dapat nilai probabilitas sig. $0,00 \geq$ 0,05 . Hal tersebut berarti bahwa hipotesis nol (H0) diterima dan Ha ditolak. Dapat disimpulkan bahwa Motivasi $\left(\mathrm{X}_{1}\right)$ secara parsial memberikan pengaruh yang signifikan terhadap Disiplin Kerja (Y) pada Kantor Kesehatan Pelabuhan Kelas I Medan.

2. Dari penelitian yang telah dilakukan di dapat hasil nilai probabilitas sig. 0,000 $\geq 0,05$. Hal tersebut berarti bahwa hipotesis nol ( $\mathrm{H} 0)$ ditolak dan Ha diterima. Dapat disimpulkan bahwa Gaya Kepemimpinan $\left(\mathrm{X}_{2}\right)$ secara parsial mempunyai pengaruh yang signifikan terhadap Disiplin Kerja (Y) pada Kantor Kesehatan Pelabuhan Kelas I Medan.

3. Ada pengaruh variabel Motivasi $\left(\mathrm{X}_{1}\right)$ dan Gaya Kepemimpinan $\left(\mathrm{X}_{2}\right)$ secara simultan terhadap Disiplin Kerja (Y) pada Kesehatan Pelabuhan Kelas I Medan yang dilihat dari uji $\mathrm{F}$ dengan nilai sig $0,000<\alpha 0,05$ menunjukkan $\mathrm{H} 0$ ditolak dan Ha diterima

4. Berarti Motivasi dan Gaya Kepemimpinan berpengaruh secara signifikan terhadap Disiplin Kerja.

\section{Saran}

Berdasarkan hasil penelitian dan bahasan yang menyangkut seluruh permasalahan yang di uji, selanjutnya dapat disampaikan saran sebagai berikut :

1. Sebaiknya motivasi yang diberikan kepada pegawai harus dapat lebih menyakinkan semua pegawai sehingga dapat mendorong seseorang mealakukan atau berbuat sesuatu pekerjaan dengan sebaik-baiknya dalam memajukan dan mencapai tujuan yang di inginkan.

2. Hendaknya pimpinan memberikan contoh yang baik kepada pegawai. menerapkan disiplin yang baik sehingga memberikan kinerja yang baik pula bagi pegawai.

3. Sebaiknya disiplin lebih ditingkatkan lagi agar kinerja dapat meningkat sehingga instansi dapat mencapai tujuan yang maksimal sesuai dengan harapan, apabila ada pegawai yang melanggar disiplin sebaiknya diberikan hukuman yang sesuai dengan peraturan yang dilanggar. 


\section{DAFTAR PUSTAKA}

Hasibuan, Malayu S.P. (2012), Manajemen Sumber Daya Manusia, Edisi Revisi. Jakarta. Bumi Aksara.

Wibowo (2011). Manajemen Perubahan, Edisi ke-3. Jakarta : Raja Grafindo Persada.

Rivai Veithzal, Ella Jauvani (2009). Manajemen Sumber Daya Manusia, Edisi ke-2. Jakarta: Raja Grafindo Persada.

Rivai Viethzal, Mulyadi Deddy (2010). Kepemimpinan dan Perilaku Orgabisasi, Edisi ke-3. Jakarta : Raja Grafindo Persada

Ratna asih (2011) yang berjudul pengaruh Motivasi dan gaya kepemimpinan terhadap Disiplin kerja Pegawai Pada Kantor Badan Narkotika Nasioanal (BNN) Kota Samarinda

Sutrisno, Edy. (2012) Manajemen Sumber Daya Manusia, Jakarta : Kencana Prenada Media Group

Sugiyono (2012) Metode Penelitian Bisnis. Cetakan Kelima Belas. Bandung : ALFABETA

Ternadi Rama (2011) yang berjudul' 'pengaruh Kepemimpinan terhadap disiplin kerja Karyawan Jurnal manjemen

Mangkunegara (2013). Manajemen Sumber Daya Manusia Perusahaan, Penerbit Remaja Rosdakarya.

Siagian, Sondang P .(2011). Manajemen Sumber Daya Manusia. Cetakan Kesembilan belas, Jakarta: Bumi Aksara. 